\title{
Osler on Migraine
}

\author{
Christopher J. Boes
}

\begin{abstract}
William Osler's 1892 textbook The Principles and Practice of Medicine became the dominant medical text in the Englishspeaking world. Osler was labeled a therapeutic nihilist by some. The topic of migraine, including treatment, was succinctly covered in his text. The objectives of this study were to review Osler's thoughts on migraine, and outline his therapeutic recommendations. Preventively Osler mentioned bromides, iron, arsenic, nitroglycerin, and cannabis. Acutely he recommended coffee, chloroform, cannabis, antipyrin, antifebrin, phenacetin, caffeine citrate, nux vomica, or ergot. He thought cannabis was the most satisfactory remedy. Osler was not a therapeutic nihilist when it came to migraine, and his treatment recommendations were similar to other writers of his time. Osler did not draw upon his personal experience to contribute new knowledge about migraine. Regardless, given the popularity and clarity of his text, Osler's well-summarized migraine chapter had a great influence on practicing physicians.

RÉSUMÉ: L'avis d'Osler sur la migraine. Le traité de William Osler, publié en 1892 et intitulé The Principles and Practice of Medicine, est devenu le texte médical dominant dans le monde anglophone. Osler a été étiqueté de nihiliste thérapeutique par certains. Dans son traité, il a abordé succinctement la migraine et son traitement. Les objectifs de cette étude étaient de revoir la pensée d'Osler sur la migraine et d'exposer brièvement ses recommandations thérapeutiques. En prévention, Osler mentionnait les bromures, le fer, l'arsenic, la nitroglycérine et le cannabis. En phase aiguë, il recommandait le café, le chloroforme, le cannabis, l'antipyrine, l'antifébrine, la phénacétine, le citrate de caféine, la noix vomique ou l'ergot. Il était d'avis que le cannabis était le remède le plus efficace. Osler n'était pas un nihiliste thérapeutique en ce qui concerne la migraine et ses recommandations de traitement étaient similaires à celles des autres écrivains de son temps. Osler n'a pas fait appel à son expérience personnelle pour présenter de nouvelles connaissances sur la migraine. Malgré cela, considérant la popularité et la clarté de son chapitre concis sur la migraine, Osler a eu une grande influence sur les médecins praticiens.
\end{abstract}

Keywords: Headache, history of neurology, migraine, William Osler

doi:10.1017/cjn.2015.6

Can. J. Neurol. Sci. 2015; 42: 144-147

Sir William Osler was considered by some to be the greatest doctor in the history of the world (Figure). ${ }^{1}$ His 1892 textbook The Principles and Practice of Medicine became the dominant medical text in the English-speaking world. ${ }^{1}$ Although he was against specialization in internal medicine, Osler had a keen interest in neurology and wrote two books on neurological topics (chorea and cerebral palsy). He once described neurology as an interesting but difficult specialty. ${ }^{2}$ The topic of migraine is succinctly covered in his 1892 text. Osler was labeled a therapeutic nihilist by some ${ }^{3}$ and a number of Osler aphorisms support this view. He noted that "the desire to take medicine is one feature which distinguishes man, the animal, from his fellow creatures." ${ }^{4} \mathrm{He}$ commented that "one of the first duties of the physician is to educate the masses not to take medication," and that "nickel-in-the-slot, press-the-button therapeutics are no good ... you cannot have a drug for every malady." 4 One of his favorite prescriptions was "Time, in divided doses.", This article will review Osler's thoughts on migraine and outline his therapeutic recommendations.

\section{METHODS}

The author reviewed the migraine chapters of the nine editions of The Principles and Practice of Medicine that Osler contributed to, as well as his publications. Biographies of Osler by Bliss and Cushing, and Bibliotheca Osleriana were reviewed. The Osler Library Archive Collections at McGill University were searched for material on migraine. Osler published no articles on migraine, and no unpublished manuscripts by Osler on migraine exist in the Osler Library Archives at McGill University.

\section{RESULTS}

In the first edition of his book, Osler divided the three-page migraine chapter into definition, etiology, symptoms, and treatment. He mentioned the following authors in the chapter: George Airy, Edward Liveing, Wharton Sinkler, T. Lauder Brunton, William Gowers, Richard Thoma, Möllendorff, Peter Wallwork Latham, and Edward Seguin. ${ }^{6}$ Osler noted that "Edward Liveing's work is the standard authority upon which most of the subsequent articles have been based."

\section{Symptoms}

In addition to describing the cardinal features of migraine in his chapter, Osler commented that "remarkable prodromata have been described, particularly in connection with vision... apparitions may appear-visions of animals, such as mice, dogs, etc." 6

\section{Pathophysiology}

Osler stated that the nature of the disease was unknown. He mentioned both the neurogenic (Liveing) and vasomotor (Möllendorff, Latham) theories in the first seven editions of his text but focused more on the vascular hypothesis by emphasizing ipsilateral temporal artery atherosclerosis in migraine. Osler commented that

From the Mayo Clinic, Department of Neurology, Rochester, MN, USA.

Received June 30, 2014. Final Revisions Submitted October 29, 2014. Correspondence to: Christopher J. Boes, Mayo Clinic, Department of Neurology, Rochester, MN, USA, 5590. Email: boes.christopher@mayo.edu 


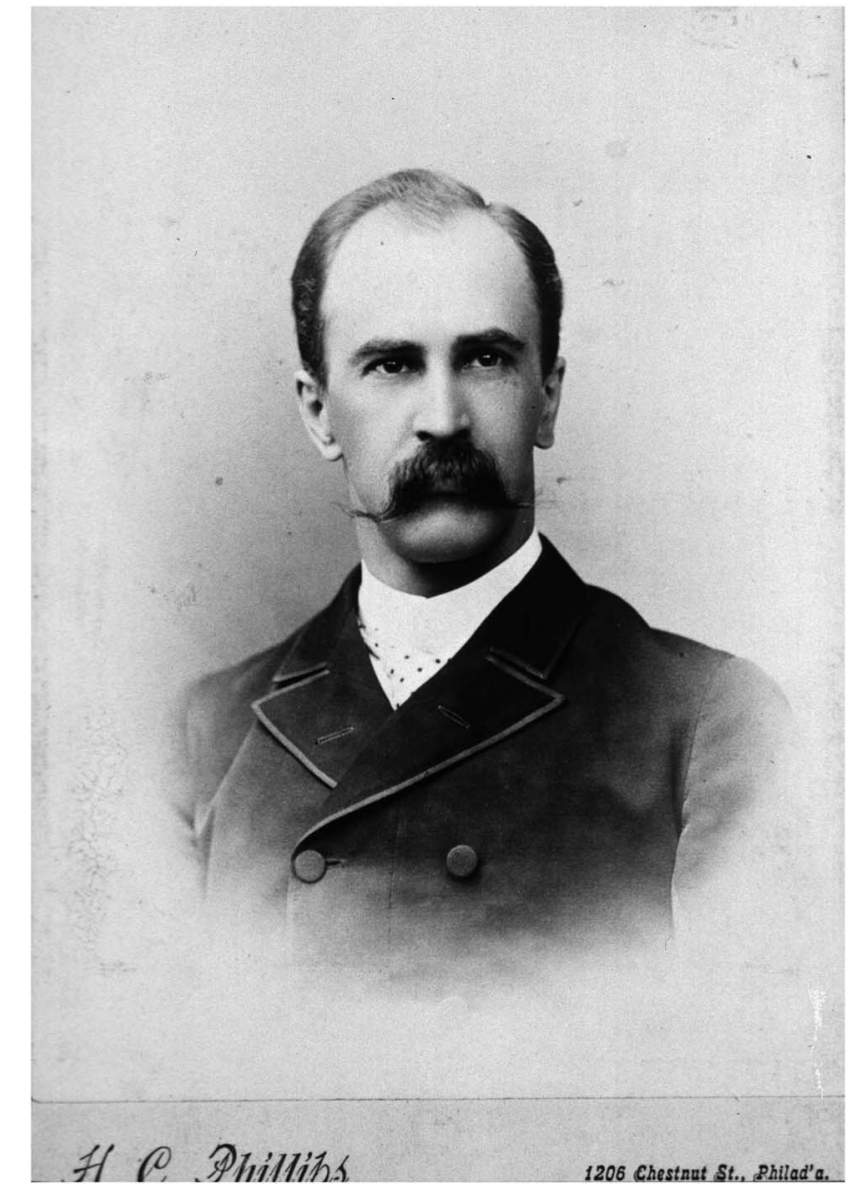

Figure: Sir William Osler. Courtesy of the National Library of Medicine.

"the temporal artery on the affected side may be firm and hard, and in a condition of arterio-sclerosis - a fact which has been confirmed anatomically by [the pathologist] Thoma." ${ }^{\text {In }}$ the chapter on angina pectoris in The Principles and Practice of Medicine, Osler commented that "it is interesting to note in connection with the almost constant sclerosis of the coronary arteries in angina that Thoma has found marked sclerosis of the temporal artery in migraine." 6 Osler also stated:

\begin{abstract}
"Mollendorf (sic), Latham, and others regard it as a vasomotor neurosis, and hold that the early symptoms are due to vaso-constrictor and the later symptoms to vaso-dilator influences. The fact of the development of arterio-sclerosis in the arteries of the affected side is a point of interest bearing upon this view." 6
\end{abstract}

In the eighth and ninth editions of his text, Osler quit mentioning Liveing's neurogenic hypothesis, and outlined four main theories of migraine pathogenesis: 1. toxic (disordered digestion, disturbed uric acid output, or "from some self-manufactured poison"), 2. vascular, 3. reflexive (from troubles in the eyes, nose, or sexual organs), and 4. transient plugging of the foramen of Monro with increased pressure in the ventricles. ${ }^{7,8}$

\section{Treatment}

Osler's treatment recommendations included avoidance of excitement, regularity in the meals, moderation in diet, and trigger avoidance. Preventively he mentioned bromides, iron and arsenic (if anemia was present), and nitroglycerin (if arterial tension was increased) but he noted that "not too much, however, should be expected of the preventive treatment of migraine... It must be confessed that in a very large proportion of cases the headaches recur in spite of all we can do." ${ }^{, 6}$ For acute attacks, Osler recommended bed rest in a quiet room, as well as a small cup of strong coffee, chloroform, Cannabis indica (also used preventively), antipyrin (phenazone; an analgesic and antipyretic), antifebrin (acetanilide), phenacetin (acetophenetidin), caffeine citrate, nux vomica (created from the seeds of the strychnine tree), or ergot. He thought cannabis was the most satisfactory remedy, and reported that antipyrin and similar drugs worked best when used at the very outset of the paroxysm. He warned against overdosing acute headache medication like antifebrin or antipyrin, noting in a patient with migraine "unpleasant collapse symptoms following a twenty-five-grain dose of antipyrin." 6 Osler ended the treatment section in the first edition of his book by stating that "electricity does not appear to be of much service." "In the third edition of his text, he mentioned washing out the stomach with water at 105 degrees and giving a brisk saline cathartic early in a migraine attack. ${ }^{9}$ In the fourth edition of his text he added the following treatment:

"And lastly, in obstinate cases, an ordinary tape seton may be inserted through the skin at the back of the neck, to be worn for three months, a plan of treatment which has the strongest possible recommendation from Mr. Whitehead, of Manchester."10

In the eighth edition Osler recommended irrigation of the colon with hot saline, and alkaline water by mouth. ${ }^{7}$

\section{Discussion}

Osler gave credit to Edward Liveing at the beginning of his chapter, underlining the importance of his 1873 book On Megrim, Sick-headache, and Some Allied Disorders: A Contribution to the Pathology of Nerve-Storms. ${ }^{11}$ Möllendorff and Peter Wallwork Latham were mentioned because they helped describe the vasomotor hypothesis of migraine, ${ }^{12,13}$ and Osler emphasized the vascular theory of migraine in his chapters over the years. Overall, he summarized the thoughts of others regarding pathophysiology, rather than hypothesizing anew.

Osler was well aware of the cardinal features of migraine, and mentioned unusual manifestations such as formed visual hallucinations. The apparitions mentioned by Osler likely refer to a paper by Silas Weir Mitchell on that topic, given the similar clinical descriptions. In 1887, Weir Mitchell published a paper entitled "Neuralgic Headaches With Apparitions of Unusual Character."14 In that paper, he described unusual "visual prodromes" in four patients with migraine. ${ }^{14}$ One patient saw a "large black and very hairy dog", followed by a severe unilateral headache. ${ }^{14}$ Other apparitions included a dead sister, a blood-covered living relative, a spider, and white-robed veiled figures. Weir Mitchell later stated that "this paper called out an interesting series of such cases 
[headaches with apparitions], not before known to medicine."15 Osler does not cite the author, which is not unusual in his textbook. There are only 137 citations in the book, although he often refers to authors by name. ${ }^{3}$

Silas Weir Mitchell was instrumental in bringing Osler from McGill University to the University of Pennsylvania and Osler dedicated his book The Cerebral Palsies of Children to him. In 1902, Weir Mitchell topped Osler's list of the seven leading American physicians. ${ }^{3}$ After Weir Mitchell's death in 1914, Osler wrote that 'during five years' residence in Philadelphia, had I been his son, he could not have done more, in every possible way, to promote my welfare."16

Osler taught that physicians should try to relieve painful symptoms and life-threatening conditions. ${ }^{1}$ Accordingly, he was not a therapeutic nihilist when it came to migraine. His cautious recommendations reflect his therapeutic principles: 1 . There is an inherent tendency in many diseases to recovery quite irrespective of any treatment, 2. Nature, in the majority of cases, is quite competent to restore the patient to health, and 3 . The functions of the physician are to co-operate with Nature. ${ }^{1}$ Osler was a therapeutic rationalist. $^{17}$

Osler's treatment recommendations were similar to those of Edward Liveing, Wharton Sinkler, William Gowers, and other physicians of the late 1800s/early 1900 s. $^{11,18-20}$ Eadie recently commented on migraine treatment in that time period:

"Treatment recommendations largely depended on the published views of prominent individual medical figures whose opinions were based on a mixture of the writings of earlier authorities and of their own interpretations of their personal experience." 20

Liveing listed numerous acute and preventive medications without clearly clarifying his favorites. Osler thought cannabis was the best acute treatment and noted that New York neurologist Edward Sequin recommended a prolonged course of the drug on a preventive basis. Seguin himself learned about cannabis preventively from the English physician Richard Greene. ${ }^{21}$ Sinkler preferred bromide of lithium acutely, and cannabis preventively. Gowers favored bromide plus cannabis acutely, and nitroglycerine preventively.

Gowers wrote extensively on migraine, and had a significant influence on Osler's textbook. Thus, it is not surprising that he was referred to in the migraine chapter. Gowers' name was mentioned more often than any other author in the first edition of Osler's textbook. ${ }^{3}$ Osler copied three tables and one figure from Gowers' Manual of Diseases of the Nervous System (tables on vocal cord paralysis, Brown-Séquard syndrome, and spells; figure of pyramidal tract) (Osler 1892 pages 807, 854, 893, 954; Gowers $1886 / 1888$ vol. 2 pg. 265 , Gowers vol. 1 pg. 158 , Gowers vol. 2 pg 25, Gowers vol. 2 pg 702). van Gijn noted recently that Osler's nervous system section mostly followed the outline of Gowers' book. $^{22}$ Osler wrote in 1888 :

"The recently completed work of Gowers on the Diseases of the Nervous System is the most solid contribution to systematic neurology produced by the British school, and as a text book on the subject stands unrivaled in any language.
We need not read between the lines to see the untiring industry, the powers of patient observation and the clear, strong judgment which have made this work possible, and have made the author, at a comparatively early age, among the highest living authorities on all matters relating to diseases of the nervous system." 23

Osler dedicated his book On Chorea and Choreiform Affections to Gowers, addressing himself as Gowers' sincere friend. Gowers wrote Osler a letter of recommendation when Osler was being considered for a job at the University of Pennsylvania, commenting that "no English physician of the same standing had achieved a wider or higher reputation." 24 Two warm letters between Osler and Gowers exist in the Osler Library Archives, highlighting their strong friendship. ${ }^{25,26}$ Gowers' son Ernest wrote Osler a letter after the death of his father. Referring to the relationship between William Osler and William Gowers, he noted that Osler had "indeed been a good friend to him all through.",27

Osler did not draw upon his personal experience as one of the best academic clinicians of his time to contribute new knowledge about migraine. He did not appear to have a significant interest in migraine, as reflected by the fact that he wrote no articles on the subject. Regardless, given the popularity (500,000 copies were printed) and clarity of his text, Osler's well-summarized migraine chapter had a great influence on practicing physicians. The author owns a copy of Bayard Horton's Osler text (the $9^{\text {th }}$ edition of The Principles and Practice of Medicine), and the migraine section is well underlined by Horton. Horton was to go on to be an expert in the area of headache at the Mayo Clinic. ${ }^{28}$

\section{DisClosures}

$\mathrm{CB}$ has nothing to disclose. This research received no specific grant from any funding agency in the public, commercial, or notfor profit sectors.

\section{REFERENCES}

1. Bliss M. William Osler: a life in medicine. Oxford; New York: Oxford University Press; 1999.

2. Osler W. A System of Practical Medicine by American authors (unsigned book review). Am J Med Sci. 1887;xciii:174-80.

3. Golden RL. A history of William Osler's The principles and practice of medicine. Montreal: Osler Library; American Osler Society; 2004.

4. Osler W, Bean RB, Bean WB. Sir William Osler aphorisms, from his bedside teachings and writings. New York: Schuman; 1950.

5. Golden RL. First edition: "the given word". A history of William Osler's The principles and practice of medicine. Montreal: Osler Library; American Osler Society; 2004, P. 51.

6. Osler W. The principles and practice of medicine: designed for the use of practitioners and students of medicine. New York: D. Appleton and Company; 1892.

7. Osler W, McCrae T. The principles and practice of medicine: designed for the use of practitioners and students of medicine, 8th ed. New York; London: D. Appleton and Company; 1912.

8. Osler W, McCrae T. The principles and practice of medicine, designed for the use of practitioners and students of medicine, 9th thoroughly rev. ed., New York: Appleton; 1920.

9. Osler W. The principles and practice of medicine: designed for the use of practitioners and students of medicine, 3rd ed. New York: D. Appleton and Co; 1899. 
10. Osler W. The principles and practice of medicine: designed for the use of practitioners and students of medicine, 4th ed., New York: D. Appleton and Company; 1901.

11. Liveing E. On megrim, sick-headache, and some allied disorders: a contribution to the pathology of nerve-storms. London: J. and A. Churchill... 1873.

12. Koehler PJ, Isler $\mathrm{H}$. The early use of ergotamine in migraine. Edward Woakes' report of 1868, its theoretical and practical background and its international reception. Cephalalgia. 2002;22:686-91.

13. Weatherall MW. The migraine theories of Liveing and Latham: a reappraisal. Brain. 2012;135:2560-8

14. Weir Mitchell S. Neuralgic headaches with apparitions of unusual character. Am J Med Sci. 1887;xciv:415-9.

15. Mitchell SW. A catalogue of the scientific and literary work of S. Weir Mitchell. Philadelphia: Published privately; 1894.

16. Osler W. Silas Weir Mitchell. BMJ. 1914;i:120-1.

17. Macht DI. Osler's prescriptions and materia medica. Trans Am Ther Soc. 1936;35:69-85.

18. Pepper W, Starr L. A system of practical medicine. Philadelphia: Lea Brothers \& Co.; 1885.
19. Gowers WR. A Manual of Diseases of the Nervous System. London: Churchill; 1888.

20. Eadie MJ. Headache: through the centuries. New York: Oxford University Press; 2012.

21. Seguin EC. Opera minora; a collection of essays, articles, lectures and addresses from 1866 to 1882 inclusive. New York: G. P. Putnam's sons; 1884.

22. van Gijn J. Book review: the life and death of British textbooks of neurology. Brain. 2010;133:2167-71.

23. Osler W. Notes and comments. Can Med Surg J. 1888;xvi:734.

24. William Gowers to Silas Weir Mitchell. Cushing Papers: Yale University Library; 1884:398.

25. William Gowers to William Osler. Cushing Papers, McGill University: Osler Library, Bibliotheca Osleriana 3562; 1894:384.

26. William Gowers to William Osler. Cushing Papers, McGill University: Osler Library, Bibliotheca Osleriana 2786; 1912:1191.

27. Ernest Gowers to William Osler. Cushing Papers, McGill University: Osler Library, Bibliotheca Osleriana 2783; 1915:1970.

28. Boes CJ. Bayard Horton's clinicopathological description of giant cell (temporal) arteritis. Cephalalgia. 2007;27:68-75. 